\title{
Granular Cell Tumor of the Vulva with a Local Recurrence after Nine Months: A Case Report
}

Vedran Madžarac ${ }^{1}$, Josip Valetić ${ }^{\text {, Tomislav Kulaš }}{ }^{1}$, Ana-Marija Valetić ${ }^{1}$ and Zlatko Hrgovićc ${ }^{* *}$

${ }^{1}$ University Department of Gynecology and Obstetrics, Merkur University Hospital, Zagreb, Croatia

${ }^{2}$ University Department of Gynecology and Obstetrics, Johann Wolfgang Goethe University, Frankfurt am Main, Germany

\begin{abstract}
Granular Cell Tumor (GCT) is a rare female genital tract tumor. Most of the tumors are benign, however malignant variants have been reported in cases of multicentric or metastatic diseases. We present a case of an infiltrative variety of benign granular cell tumor that was totally excised under general anesthesia. Wider local excision was made following recurrence of the tumor after nine months. There was no evidence of the disease during four years of follow up.
\end{abstract}

Keywords: Granular cell tumor; Vulva; Local recurrence

\section{Introduction}

Granular Cell Tumor (GCT) is a rare neoplastic lesion of the skin and soft tissue. Most of the immunohistochemical and ultrastructural evidences support its neurogenic origin of Schwann cell derivation [1]. Vulvar involvement has been reported in $5-16 \%$ of these tumors [2]. Most GTCs are benign, however some have tendency to recur locally, primary if the advancing edge of the tumor is infiltrative. Malignant transformation is rare, and has been reported in $1-2 \%$ of these tumors [3]. In this report a case of vulvar granular cell tumor with a local recurrence after nine months is reported.

\section{Case Report}

A 48-year old female with a history of stress urinary incontinence and painless nodule in the upper right labia was admitted to hospital for Mini-Arc ${ }^{\mathrm{Tx}}$ Sling procedure and excision of tumor. Examination of the vulva revealed a $2 \mathrm{~cm} \times 2 \mathrm{~cm}$, firm nodular mass that was previously misdiagnosed as fibroma. The patient reported that the nodule had increased in size over several months. She underwent local excision of the tumor during Mini-Arc procedure under general anesthesia. Her postoperative course was uneventful. Histological examination showed clusters of large cells with a granular eosinophilic cytoplasm and small central nuclei, without atypia or mitoses (Figure 1). Imunohistochemical stains for PAS, NSE and S- 100 protein were positive and SMA and cytokeratin negative. A diagnosis of benign granular cell tumor of the infiltrating variety was made. Surgical margins were negative. Nine months after initial surgery, on a followup exam, asymptomatic lump, $0.5 \mathrm{~cm}$ in size, was noted on a right labia, close to excision site. Repeated local excision with wide margins was carried out since there was no evidence for distant metastases and frozen section showed granular cell tumor with no histologic features of malignancy. There were no signs of recurrence of the tumor during four years of follow up.

\section{Discussion}

GCT is a rare tumor, occuring in a wide variety of visceral and cutaneous sites throughout the body [4]. The most common location of GCT in the female genital tract is on the labia followed by perineal area and vaginal introitus. These tumors are frequently diagnosed as an incidental finding during check-up since they usually occur as benign, asymptomatic, solitary, skin-colored nodule. About 1-2\% of these tumors are malignant with highly aggressive behavior. Metastases can occur via lymphatic spread to regional lymph nodes and hematogeneous spread to liver, lungs and bones [5]. Several authors have proposed criteria that should enable early differentiation of benign and malignant variants. Clinical features associated with increased malignant potential are: rapid tumor growth, tumor size exceeding $4 \mathrm{~cm}$, local recurrence, and advanced age [6,7]. The literature identifies six important histologic criteria that are associated with malignancy of these tumors: necrosis, spindling tumor cells, vesicular nuclei with prominent nucleoli, increased mitotic rate (two mitoses/ ten high- power fields at 200X magnification), increased N:C ratio, and pleomorphism [8]. Finding of atypical mitoses is considered to be the most important predictive factor for subsequent aggressive clinical behavior of tumor. Immunohistochemical methods should be used as a part of standard procedure of early detection of malignant GCTs. In the study of Fanburg-Smith et al. malignant tumors had Ki-67 immunopositivity in up to $30 \%$ and p53 overexpression were seen in more than $10 \%$ of the cell population [9]. In a case of granular

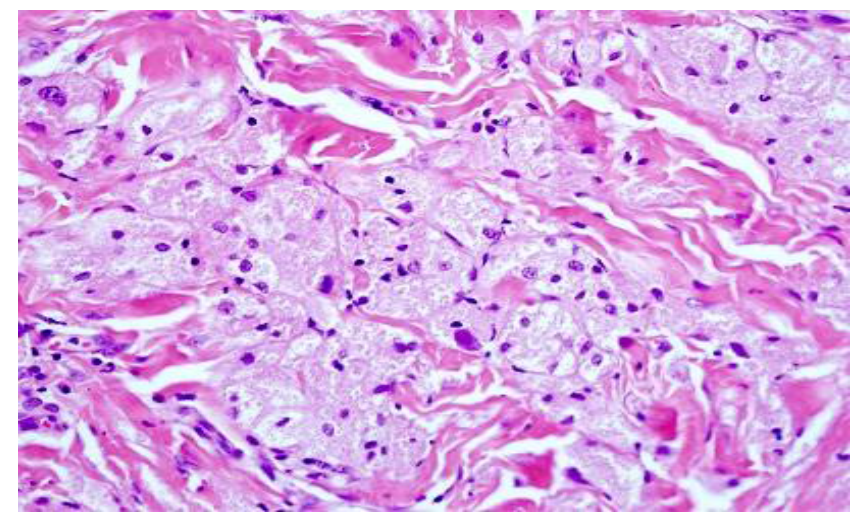

Figure 1: Granular cell tumour. Cells with granular eosinophilic cytoplasm. (H\&E, x40).

*Corresponding author: Zlatko Hrgovic, University Department of Gynecology and Obstetrics, Johann Wolfgang Goethe University, Frankfurt am Main, Germany, Tel: +4969 293 000; Fax: +49 69291 697; E-mail: info@hrgovic.de

Received September 14, 2015; Accepted October 23, 2015; Published October 30,2015

Citation: Madžarac V, Valetić J, Kulaš T, Valetić AM, Hrgović Z (2015) Granular Cell Tumor of the Vulva with a Local Recurrence after Nine Months: A Case Report. J Clin Case Rep 5: 625. doi:10.4172/2165-7920.1000625

Copyright: (c) 2015 Madžarac V, et al. This is an open-access article distributed under the terms of the Creative Commons Attribution License, which permits unrestricted use, distribution, and reproduction in any medium, provided the original author and source are credited. 
cell tumor of the vulva with local recurrence and distant metastases, chromosomal imbalances were studied using Comparative Genomic Hybridization (CGH). The only significant DNA copy number changes were gains for $5 \mathrm{q}, 7 \mathrm{q}, 19$ and 20 . Chromosomal loses were not detected [10]. Granular cell tumor is treated by local surgical excision. In case of residual tumor in resection margins, wider local excision is recommended. The overall recurrence for benign granular cell tumors is low, however, recurrence is more likely if the advancing edge of the tumor is infiltrative and ill-defined rather than nodular and distinct [11]. The incidence of recurrence is somewhat greater in case of inadequate excision which results from the fact that granular cell tumors of the vulva are poorly encapsulated and tend to infiltrate the adjacent tissue [12]. In case of malignant GCTs radical local surgery with regional lymph node dissection is the adequate procedure. Since these tumors are mesodermal in origin, vascular reduction is better tolerated than surrounding tissue, thus poor response to radiotherapy or chemotherapy can be expected. Given the malignant potential of these tumors if any lesion reoccurs it is necessary to make examinations to exclude distant metastases with prompt biopsy, followed by histological and imunohistochemical reevaluation of the lesion [13]. In our case extensive staging procedure excluded distant metastases. Histological evaluation showed that tumor was benign with infiltrative growth pattern since advancing edge of the tumor was irregular and tumor cells were extending into the dermis and soft tissue. To our knowledge only rare cases were described where malignant GCTs retained benign histologic appearance [14]. In accordance with these findings only wider local excision was carried out without regional lymph node dissection. During follow-up period there was no sign of recurrence. However, long term follow-up is important, especially in cases with local recurrence, since it may be the first indication of aggressive behavior, benign histologic features notwithstanding.

\section{References}

1. Abenoza P, Sibley RK (1987) Granular cell myoma and schwannoma: fine structural and immunohistochemical study. Ultrastruct Pathol 11: 19-28.

2. Simone J, Schneider GT, Begneaud W, Harms K (1996) Granular cell tumor of the vulva: literature review and case report. J La State Med Soc 148: 539-541.

3. Zhang H, Li L, Hao J, Liu M, Shi M, et al. (2011) Granular cell tumor from a 7-year swelling of the vulva: a case report. Arch Gynecol Obstet 284: 1293-1294.

4. Hong SC, Lim YK, Chew SH, Chia YN, Yam KL (2012) Case report of granular cell tumor of the vulva and review of current literature. Gynecol Oncol Case Rep 3: 20-22.

5. Jardines L, Cheung L, LiVolsi V, Hendrickson S, Brooks JJ (1994) Malignant granular cell tumors: report of a case and review of the literature. Surgery 116: 49-54.

6. Enzinger FM, Weiss SW. Soft tissue tumors. St. Louis, MO, Mosby-Yearbook, 199, 872-875.

7. Cheewakriangkrai C, Sharma S, Deeb G, Lele S (2005) A rare female genital tract tumor: benign granular cell tumor of vulva: case report and review of the literature. Gynecol Oncol 97: 656-658.

8. Fanburg-Smith JC, Meis-Kindblom JM, Fante R, Kindblom LG (1998) Malignant granular cell tumor of soft tissue: diagnostic criteria and clinicopathologic correlation. Am J Surg Pathol 22: 779-794.

9. Schmidt O, Fleckenstein GH, Gunawan B, Füzesi L, Emons G (2003) Recurrence and rapid metastasis formation of a granular cell tumor of the vulva. Eur J Obstet Gynecol Reprod Biol 106: 219-221.

10. Althausen AM, Kowalski DP, Ludwig ME, Curry SL, Greene JF (2000) Granular cell tumors: a new clinically important histologic finding. Gynecol Oncol 77 310-313.

11. Chambers DC (1979) Granular cell myoblastoma of the vulva. J Natl Med Assoc 71: 1071-1073.

12. Levavi H, Sabah G, Kaplan B, Tytiun Y, Braslavsky D, et al. (2006) Granular cell tumor of the vulva: six new cases. Arch Gynecol Obstet 273: 246-249.

13. Majmudar B, Castellano PZ, Wilson RW, Siegel RJ (1990) Granular cell tumors of the vulva. J Reprod Med 35: 1008-1014.

14. Althausen AM, Kowalski DP, Ludwig ME, Curry SL, Greene JF (2000) Granular cell tumors: a new clinically important histologic finding. Gynecol Oncol 77 310-313. 